\title{
PEMBACAAN SINYAL OTOT PADA BAGIAN KEPALA MENGGUNAKAN SENSOR ELEKTROMIOGRAFI (EMG) DAN SCILAB
}

\author{
1Nico Hendrawan Santoso*), ${ }^{1}$ Florentinus Budi Setiawan \\ 1Program Studi Teknik Elektro, Fakultas Teknik, Universitas katolik soegijapranata
}

nicohendrawan@gmail.com ${ }^{\star}$ )

\begin{abstract}
Abstrak
Seiring dengan perkembangan jaman, pengaplikasan ilmu robotika juga semakin berkembang dan mulai masuk ke berbagi bidang, khususnya bidang biomedis yang akan sangat bermanfaat untuk umat manusia untuk kelangsungan hidupnya.

Pada penelitian ini penulis akan membahas tentang perancangan electromiografi (EMG) untuk mendeteksi adanya aktivitas listrik di dalam otot manusia. Pada penelitian ini penulis mengukur pada bagian kepala yaitu otot dahi, otot pipi, otot rahang, otot belakang telinga dan otot leher. amplitudo yang sangat kecil maka diperlukan elektroda sebagai media untuk mendeteksi sinyal tersebut, elektroda di lekatkan pada bagian otot besar yang mempunyai denyut nadi paling kuat. Kemudian sinyal dikuatkan menggunakan rangkaian penguat AD620 dengan 1000 kali penguatan. Hasil dari pengukuran otot wajah dikuatkan menggunakan elektromiografi supaya dapat direkam kemudian rekaman berupa suara diolah menggunakan Scilab.
\end{abstract}

Kata Kunci : Elektromiografi, Amplifier, Elektroda

\section{Pendahuluan}

Di jaman yang serba modern ini, perkembangan teknologi berkembang sangat pesat serta berperan penting dalam kehidupan sehari-hari manusia. Electromyography (EMG) adalah proses merekam aktivitas elektrik dari otot, untuk menentukan apakah sedang melakukan kontraksi atau tidak. Sinyal elektromiografi adalah sinyal biomedis yang diperoleh melalui respons listrik yang dihasilkan dalam otot selama kontraksi yang merepresentasikan aktivitas neuromuskuler[1]. Fungsi otot sangat berperan penting dalam setiap aktivitas manusia, misalnya dalam bekerja, berolah raga, belajar bahkan tidur tidak terlepas dari kerja otot. Semakin besar otot mengeluarkan tenaga maka frekuensinya akan semakin besar, sebagian besar perangkat elektronika ini merupakan perangkat elektronika dengan sinyal lemah. Perangkat elektronika dengan sinyal lemah ini diantaranya banyak terdapat pada instrumentasi medis. Beberapa instrumentasi medis ini membutuhkan filter untuk melewatkan sinyal dengan rentang frekuensi tertentu. Penelitian tentang EMG memanfaatkan sinyal elektrik yang ada dalam tubuh manusia agar dapat digunakan sebagai input kendali suatu sistem yang dalam hal ini mengambil sinyal-sinyal EMG hasil dariaktivitas otot yang mengandung informasi tentang keadaan otot tersebut.

Pada saat otot berkontraksi maka akan menghasilkan sinyal-sinyal impuls yang dapat di baca oleh elektroda yang kemudian dapat di kuatkan dan di olah menggunakan Scilab.

\section{Dasar Teori}

Sebelum membahas rancangan yang di buat, harus di pahami terlebih dahulu mekanisme kerja otot manusia. Otot merupakan alat gerak aktif dalam sistem gerak manusia, rangka yang menyokong tubuh manusia di gerakkan oleh otot yang menempel pada rangka. Otot memiliki karakteristik yang berbeda, namun pada dasarnya tersusun atas protein kontraktil yang mampu membangkitkan gerakan. Impuls yang di hasilkan saat otot sedang tegang dibaca menggunakan elektroda sebagai ACTION POTENTIAL yang dikenal sebagai MOTOR UNIT ACTION POTENTIAL (MUAP). Saat terjadinya MUAP, terdapat peranan ion Natrium $\left(\mathrm{Na}^{+}\right)$dan Potasium $\left(\mathrm{K}^{+}\right)$, yang berpindah pindah menyebabkan perbedaan potential otot.

Sinyal tegangan ini terjadi karena terjadi proses Polarisasi dan Depolarisasi 2 Ion penting dalam sel-sel otot, Ion tersebut adalah Natrium(Na+) dan Potasium(K+), Proses terjadinya tegangan di bagi menjadi 3 bagian, yaitu Polarisasi (Penegangan otot), Depolarisasi (Pelemasan otot), dan Kondisi istirahat[2].

Dengan teori diatas, maka di buatlah diagram sederhana untuk memberi gambaran secara sederhana dalam pengolahan sinyal otot agar mudah untuk di olah menggunakan aplikasi Scilab.

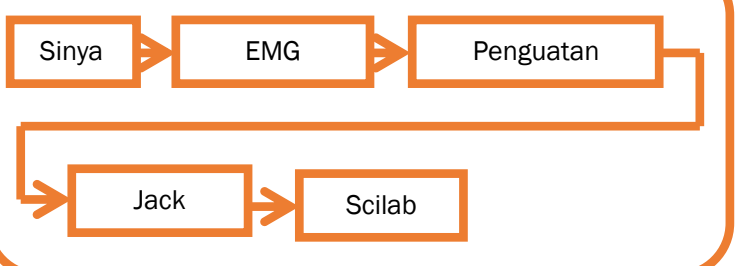




\subsection{Elektroda}

Elektroda merupakan faktor penting dalam pengukuran ini, karena sebagai awal masuknya sinyal yang akan dibaca oleh alat ini, dalam pengujian alat di gunakan elektroda jenis Gel.Elektroda yang digunakan adalah bipolar 2 elektroda yang aktif diletakkan secara berdekatan di otot yang akan di ukur dan 1 sebagai ground. Elektroda diletakan pada permukaan kulit yang mengalami kontraksi sesuai dengan gerakan yang dilakukan.

Elektroda berfungsi untuk membaca dan menghantarkan sinyal otot dari permukaan kulit ke rangkaian EMG[4]. Sensor tersebut terbuat dari bahan Ag | $\mathrm{AgCl}$, Bagian AgC1 memudahkan arus yang melewati belokan antara Electrolit dan Elektroda. Dalam elektroda ini terdapat gel yang menempel langsung pada kulit, gel ini yang akan mendeteksi listrik dalam tubuh manusia yang kemudian ion yang di tangkap oleh elektroda ini masuk dan di proses di dalam penguat Elektromiografi (EMG). Dengan menggunakan elektroda gel ini pengukuran yang dilakukan lebih efektif karena noise yang masuk jauh lebih sedikit.

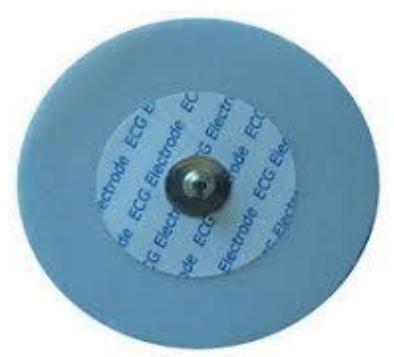

Gambar 2. Elektroda Perak klorida dengan dilapisi Gel

\subsection{Operasional Amplifier}

Operasional amplifier (Op-Amp) adalah komponen elektronika yang merupakan suatu rangkaian integrated circuit (IC) yang memiliki dua input inverting dan non-inverting dengan sebuah terminal output. Dimana rangkaian umpan balik dapat ditambahkan untuk mengendalikan karakteristik tanggapan keseluruhan pada operasional amplifier (Op-Amp). Pada dasarnya operasional amplifier (Op-Amp) merupakan suatu penguat diferensial yang memiliki 2 inputdan 1 output. Op-amp ini digunakan untuk membentuk fungsi-fungsi linier yang bermacam-macam atau dapat juga digunakan untuk operasi-operasi tak linier, dan seringkali disebut sebagai rangkaian 
terpadu linier dasar. Penguat operasional (Op-Amp) merupakan komponen elektronika analog yang berfungsi sebagai amplifier multiguna dalam bentuk IC[5]. dan memiliki simbol sebagai berikut :

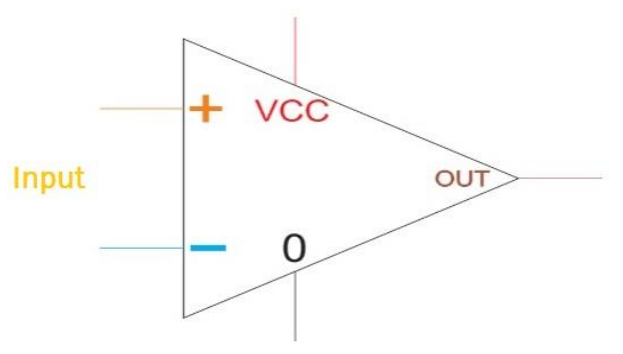

Gambar 3. Simbol OP-AMP

\subsection{Konektor Audio Jack $3.5 \mathrm{~mm}$}

Konektor $3.5 \mathrm{~mm}$ jack dijadikan standart internasional karena kemampuan dan fiturnya yang lebih memadai ketimbang konektor audio jack $2.5 \mathrm{~mm}$. kata $3.5 \mathrm{~mm}$ jack sendiri diambil dari ukuran diameter konektor tersebut. Konektor $3.5 \mathrm{~mm}$ jack ini juga memiliki tipenya sendirisendiri.
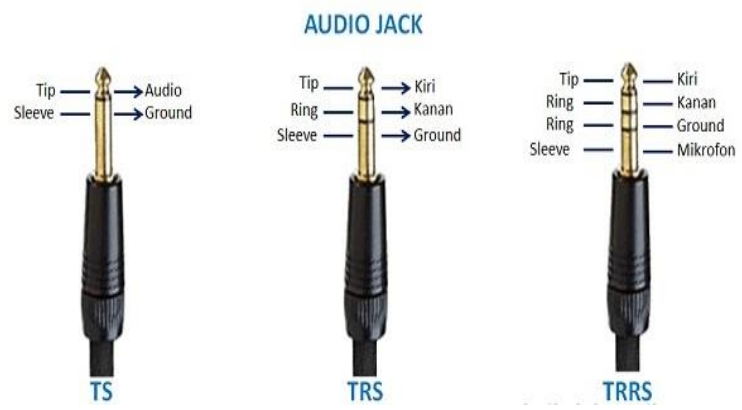

Gambar 4. Jenis - jenis audio jack

\section{a. Audio Jack TS (Tip-Sleeve)}

Audio Jack TS (Tip-Sleeve) adalah Audio Jack yang terdiri dari dua konduktor saja yaitu bagian konduktor Tip dan bagian Konduktor Sleeve. Tip biasanya dihubungkan ke signal audio sedangkan bagian Sleeve dihubungkan ke Ground. Audio Jack TS ini biasanya digunakan untuk mikrofon ataupun Audio yang bermodel mono (suara kanan dan suara kiri sama saja).

\section{b. Audio Jack TRS (Tip-Ring-Sleeve)}

Audio Jack TRS (Tip-Ring-Sleeve) ini memiliki tiga bagian konduktor yaitu konduktor Tip, konduktor Ring dan konduktor Sleeve. Pada umumnya, bagian konduktor Tip dihubungkan ke kanal kiri audio (Left Channel) dan bagian Ring dihubungkan ke kanal kanan audio (Right Channel) sedangkan bagian konduktor Sleeve dihubungkan ke Ground. Audio Jack TRS ini mendukung audio dengan mode Stereo.

\section{c. Audio Jack TRRS (Tip-Ring-Ring-Sleeve)}

Audio Jack tipe TRRS (Tip-Ring-RingSleeve) adalah tipe Audio Jack yang paling lengkap karena terdapat empat bagian konduktor yaitu 1 konduktor Tip, 2 konduktor Ring dan 1 konduktor Sleeve. Biasanya, Audio Jack TRRS yang berukuran $3,5 \mathrm{~mm}$ ini digunakan untuk mendengarkan musik dan berkomunikasi di hampir semua jenis Smartphone yang beredar di pasaran saat ini. Konfigurasi Audio Jack TRRS ini pada umumnya adalah konduktor Tip untuk audio kanal kiri (Left Channel), konduktor Ring pertama untuk audio kanal kanan (Right Channel), konduktor Ring kedua untuk Ground dan konduktor Sleeve untuk Mikrofon.

\section{Perancangan Alat}

Pada pengukuran otot, menggunakan sensor elektromiografi tanpa filter yang dikombinasikan dengan audio. Hasil dari pengukuran otot diolah menggunakan scilab.

\section{a. Rangkaian Analog}

Rangkaian analog yang di gunakan terdiri dari tiga buah OP-AMP, OP-AMP pertama adalah Penguat Instrumentasi AD620 yang secara spesifik di gunakan dalam aplikasi EMG, fungsi dari penguat instrumentasi sendiri adalah untuk menguatkan sinyal otot yang di peroleh dari permukaan kulit. Pemilihan penguat instrumentasi AD620 di dasari oleh aplikasi pokok yang di cantumkan dalam Datasheet produk tersebut[3].

AD620 sangatlah minimalis karena hanya membutuhkan 1 buat resistor untuk menentukan nilai penguatannya, Rumus untuk menentukan nilai resistor yang di gunakan dan penguatan yang di hasilkan adalah sebagai berikut:

$$
R g=1+\frac{49,9 k}{G-1}[3]
$$

$\mathrm{Rg}=$ Nilai Resistor yang akan digunakan $\mathrm{G}=$ Nilai penguatan yang diinginkan

dan dapat di jabarkan tiap-tiap bagian rangkaiannya. 


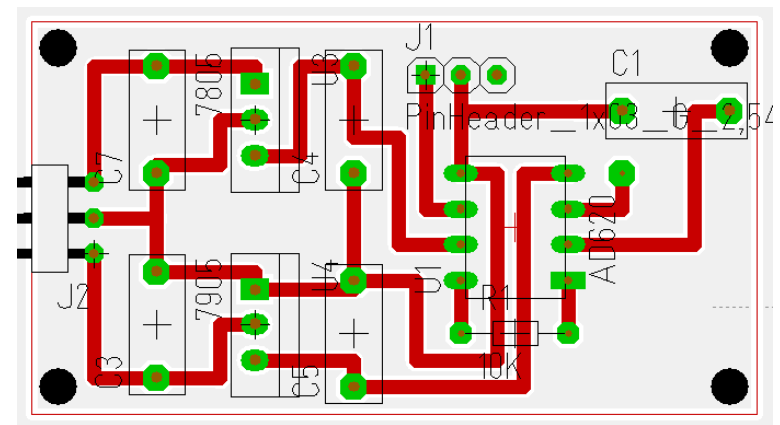

Gambar 5. Desain komponen pada PCB

\section{b. IC AD620}

IC AD620 berfungsi untuk menguatkan sinyal otot yang dibaca oleh elektroda dalam bentuk MUAP (Motor Unit Action Potential). Penguat ini digunakan karena sinyal otot yang terbaca oleh elektroda sangatlah kecil, sehingga dibutuhkan penguat agar sinyal dapat diproses dengan lebih mudah[2]. IC AD620 yang spesifik untuk di gunakan dalam aplikasi pembacaan sinyal EMG maupun ECG selain itu pemakaiannya relatif jauh lebih mudah di bandingkan dengan memakai rangkaian Op-Amp lainnya.

Dengan hanya menambahkan sebuah resistor untuk mengatur nilai penguatan Op-Amp tersebut maka rangkaian yang di gunakan dapat di buat seminimalis mungkin.

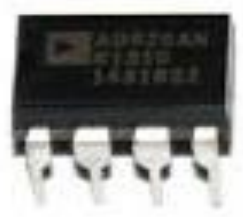

Gambar 6. Bentuk fisik AD620

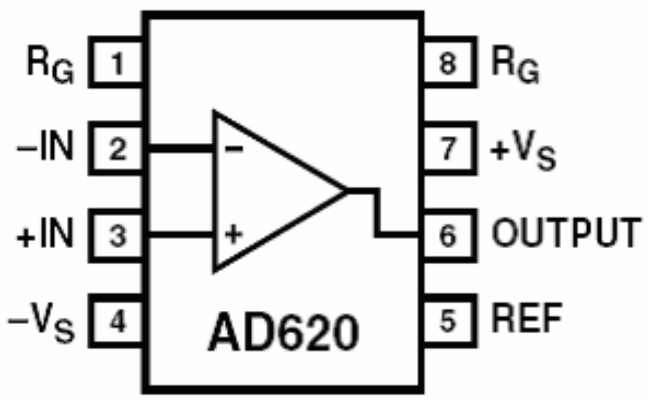

Gambar 7. Pinout AD620

\section{c. Scilab}

Scilab adalah suatu perangkat lunak yang dikembangkan untuk komputasi numeric dan visualisasi data, Proses rekaman otot yang berupa audio dapat kita olah menggunakan scilab dengan program[5][6]. Sebagai berikut :

Step 1

$\mathrm{t}=1: 8000 ; \quad$ (Range Gelombang)

y=wavread('lokasi file’); (Upload file)

plot(y) (Menampilkan Gelombang)

Step 2

$\mathrm{x}=\mathrm{abs}(\mathrm{fft}(\mathrm{y})) ; \quad$ (Mengubah suatu data dalam domain waktu menjadi data dalam domain frekuensi)

$\operatorname{plot}(\mathrm{x})$

(Menampilkan Gelombang)

Scilab juga dilengkapi dengan sistem bantuan (help) yang cukup baik, untuk melihat sistem bantuan (help), gunakan menu ? _ Scilab Help. Pada jendela bantuan, kita dapat memperoleh penjelasan yang detail mengenai suatu fungsi atau operator tertentu[5].

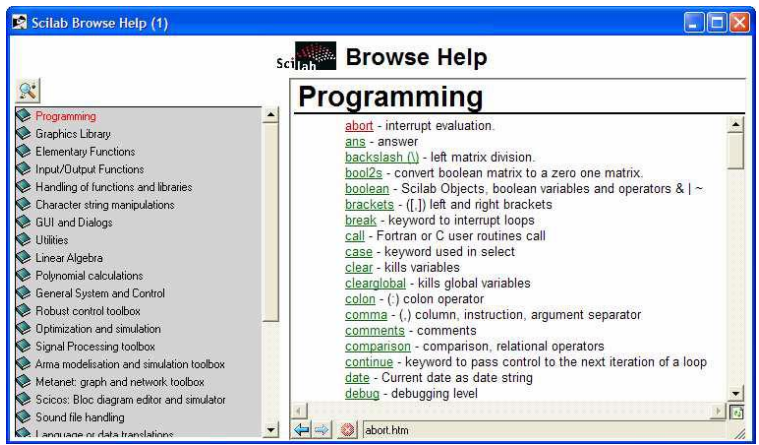

Gambar 8. Jendela bantuan

\section{Pengujian dan Analisis}

Pada penelitian ini menggunakan elektromiografi sebagai sensor otot untuk pengambilan data. Hasil sinyal tegangan otot kemudian direkam dan diolah menggunakan scilab.

Karena sinyal otot pada wajah dan sekitar kepala sangat kecil maka harus dikuatkan terlebih dahulu sebelum direkam dan diolah dengan Scilab. Dalam rancangan elektromiogafi terdapat IC AD620 yang berfungsi sebagai penguat dan dapat menguatkan hingga 1000 kali. 
Seminar Nasional Instrumentasi, Kontrol dan Otomasi (SNIKO) 2018 Bandung, Indonesia, 10-11 Desember 2018

Saat pengujian dilakukan pengukuran beberapa otot pada kepala diantaranya adalah otot frontalis atau dahi, otot zygomaticus atau pipi, otot sternocleidomastoideus atau belakang telinga, otot maseter atau rahang dan otot sternohyoideus atau leher. Berikut adalah titik-titik pengukuran, hasil osiloskop dan hasil scilab :

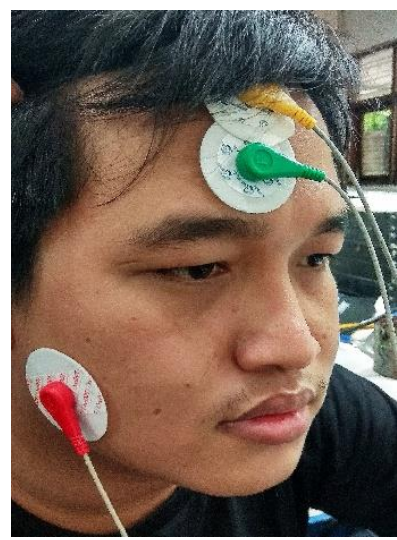

Gambar 9. Otot dahi atau frontalis

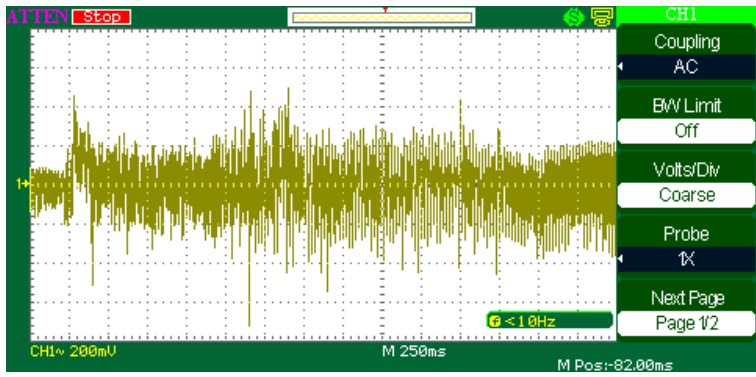

Gambar 10. Hasil sinyal otot dahi pada osiloskop

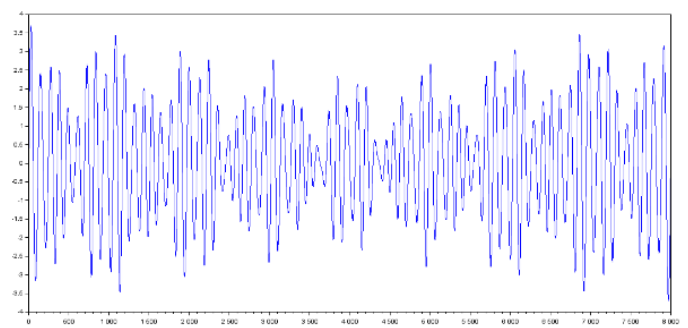

Gambar 11. Hasil sinyal pada scilab

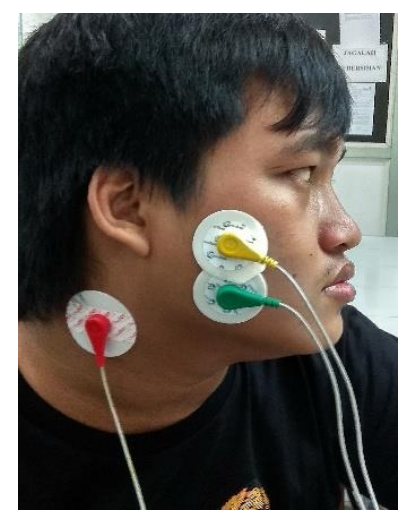

Gambar 12. Otot rahang atau maseter

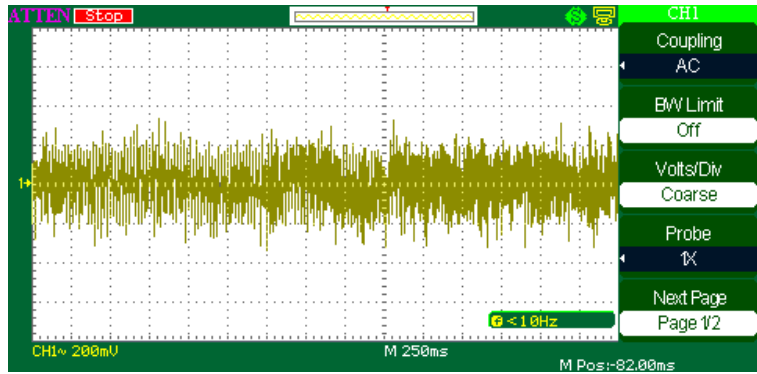

Gambar 13. Hasil sinyal otot rahang pada osiloskop

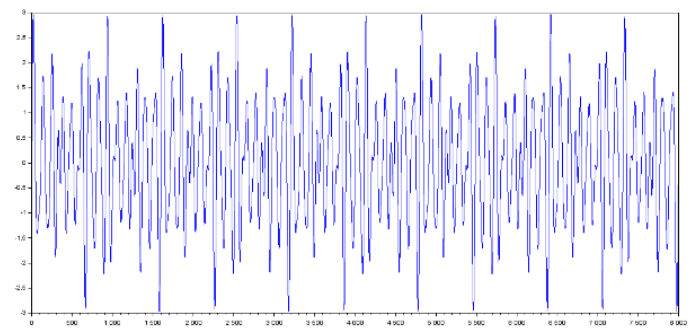

Gambar 14. Hasil sinyal pada scilab

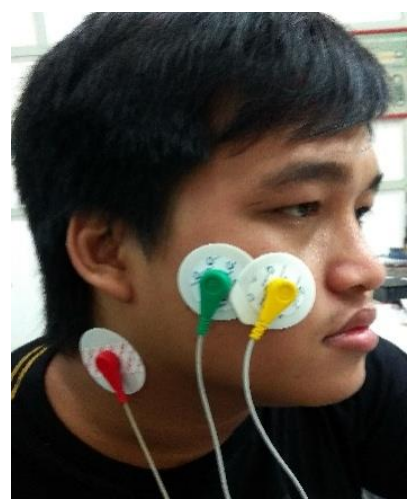

Gambar 15. Otot pipi atau zygomaticus 
Seminar Nasional Instrumentasi, Kontrol dan Otomasi (SNIKO) 2018 Bandung, Indonesia, 10-11 Desember 2018

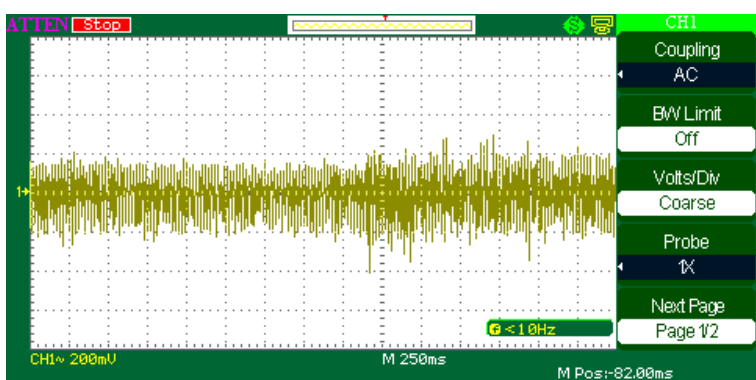

Gambar 16. Hasil sinyal otot pipi pada osiloskop

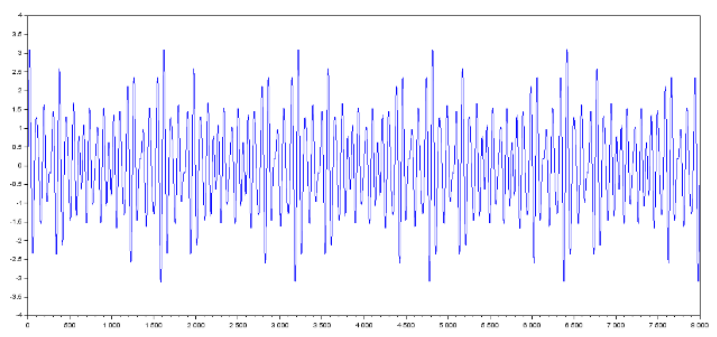

Gambar 17. Hasil pada scilab

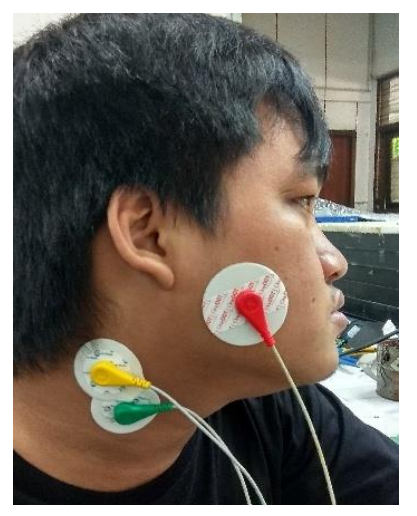

Gambar 18. Otot belakang telinga atau sternocleidomastoideus

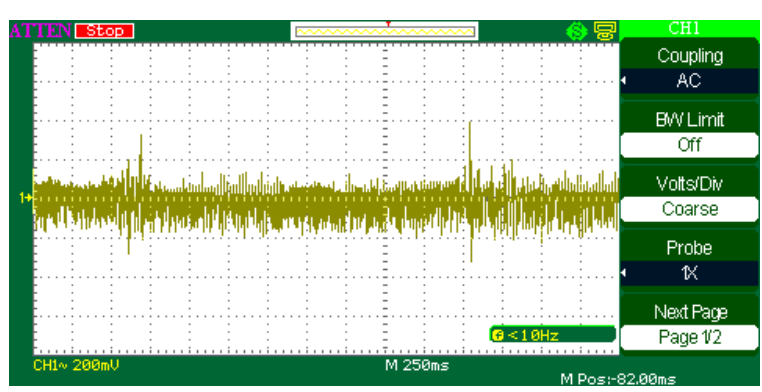

Gambar 19. Hasil sinyal otot belakang telinga pada osiloskop

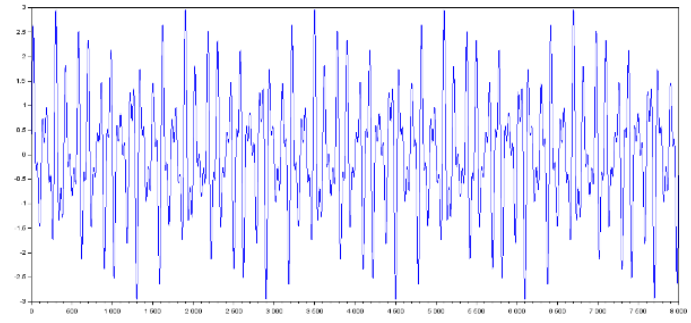

Gambar 20. Hasil pada scilab

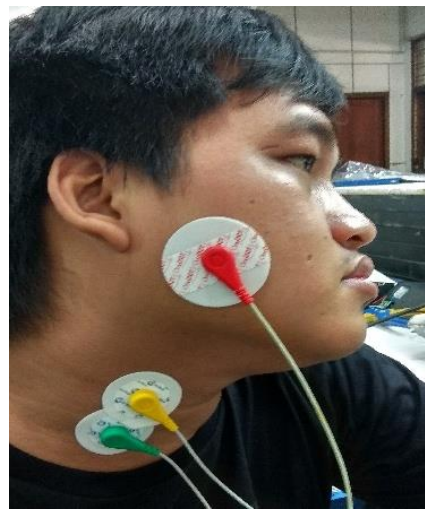

Gambar 21. Otot leher atau sternohyoideus

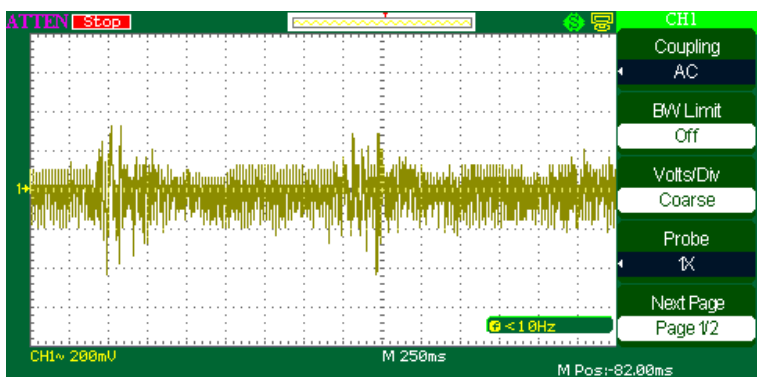

Gambar 22. Hasil sinyal otot leher pada osiloskop

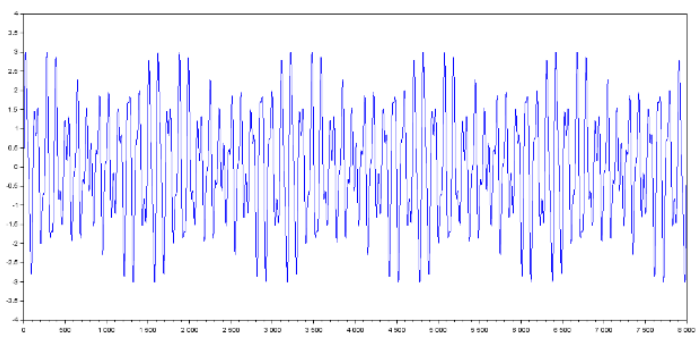

Gambar 23. Hasil pada scilab 


\section{Kesimpulan}

Setelah melakukan pengujian dan pengamatan telah didapatkan kesimpulan yang berdasarkan dari pengukuran sensor elektromiografi yaitu :

1. Rangkaian penguat sinyal pada pengukuran otot wajah dapat berfungsi dengan baik yaitu menguatkan sinyal otot kemudian direkam dan diolah menggunakan Scilab

2. Program pada pengolahan suara otot yang direkam kemudian diolah dengan Scilab berjalan dengan baik

3. Hasil dari pengukuran otot wajah dikuatkan menggunakan elektromiografi supaya dapat direkam.

4. Nilai yang dihasilkan pada saat pengukuran berbeda-beda dikarenakan tingkat ketebalan lemak dan kekuatan pada tiap otot manusia

\section{Daftar Pustaka}

[1] Kevin Eka Pramudita, FB. Setiawan, Siswanto, "Interface and display of Electromyograph signal wireless measurements" Proc. of 2014 1st Int. Conf. on Information Tech., Computer, and Electrical Engineering (ICITACEE), 2014.

[2] FB. Setiawan, Siswanto, "Multi Channel Electromyograph (EMG) Signal Acqiusition using Microcontroller with Rectifier", Proc. of 2016 3rd Int. Conf. on Information Tech., Computer, and Electrical Engineering (ICITACEE), 2016.

[3] AD620 datasheet, Analog Device, 2010.

[4] Rietsh, E., An Introduction to Scilab from a Matlab User's Point of View Version 2.61.0,2002.

[5] Ricky Fajar Adiputra, FB. Setiawan, "ROBOT ARM CONTROLLED BY MUSCLE TENSION BASED ON ELECTROMYOGRAPHY AND PIC18F4550" Proc. of 2016 3rd Int. Conf. on Information Tech., Computer, and Electrical Engineering (ICITACEE), 2016.

[6] Arief,S., Scilab - Perangkat lunak gratis untuk komputasi numeric dan visualisasi data. 2003.

[7] Chapra, S.C., Canale, R.P., Numerical Methods for Engineers with Programming and Software Applications. WCB/McGraw Hill,Singapore, 1998. 